\title{
Product Price Competition and Cooperation, and Stability of Enterprise Cooperation Will
}

\author{
Jinchao Wang \\ Jilin Agricultural University, Changchun Jilin, 130118, China
}

Key words: Price competition and cooperation, Cooperation will stability, Correlation analysis.

\begin{abstract}
In enterprise development process, the price is a key influence factor for enterprises to gain the initiative status of market competition. Whether cooperation will between enterprises can achieve certain stability is also closely related to product price. Enterprise product price competition and cooperation, and stability of enterprise cooperation will are a long-term topic for discussion. How to achieve balanced development of the two is a research emphasis of this paper.
\end{abstract}

\section{Introduction}

Product price is a very important part in enterprise development. Meanwhile, it is an important reference factor for enterprises to occupy the market. The effects of product price on enterprise development are not same in different periods. In general, lower product price is beneficial to enterprises to develop market and maintain market share in fierce market competitions. Of course, such price factor is based on similar product quality, after-sale service and enterprise brand. The change factor of such product price is closely related to enterprise profit and enterprise operation. The largest influence of product price on an enterprise is reflected in cooperation will with other enterprises. This is also the greatest significance of studying product price competition and cooperation, and stability of enterprise cooperation will. From the perspective of enterprise cooperation partners, the stability of cooperation will is mostly influenced by product price, except product quality, after-sale service and brand. The change in product price will have a direct influence on enterprise cooperation will. The stability of such cooperation will is closely related to enterprise development.

\section{Analysis of product price competition and cooperation}

Product price competition and cooperation refer to price change phenomenon which combines factors in multiple aspects. For enterprise market expansion, product price adjustment is a very important means. For example, for the enterprises in the initial stage of market occupation, they usually increase market share, stimulate consumers' consuming desire and enhance cooperation will with other enterprises through decreasing product price. The decrease in product price will inevitably result in the reduction of enterprise profit, and the increase of product sales volume will increase the total sales. Thus, total profit scale increases. The decrease in the profit of single product will lead to the reduction of total profit scale. To gain the maximum profit, enterprises will continuously adjust and balance the relationship between the two so as to gain higher profit. On the other hand, product price directly influences the stability of cooperation will. In other words, for the enterprises who have cooperative relationship with the enterprise, lower the product price is, the higher stability of cooperation will under the same product quality. Conversely, the stability of cooperation will is lower. The influence of product price competition and cooperation on enterprises are reflected in many aspects. For instance, enterprises will reduce product price in order to occupy the market and increase total sales, which may result in the decrease in total profit. To ensure profit level, the enterprises must reduce the cost. With unchanged product quality, enterprises must improve management level or update production equipment in order to improve production efficiency and reduce production cost. Thus, product price competition and cooperation are closely related to enterprise management level and capital strength etc. Besides, product price competition and cooperation are greatly related to external 
economic environment. Such economic environment correlation is mainly correlation external market economy. If market competition is more fierce, the possibility of reducing product price is larger ${ }^{[1]}$. In other words, product price competition and cooperation are not just embodied in product price change, but related to enterprise management level, comprehensive strength and economic environment as well as long-term development.

\section{Analysis of enterprise cooperation stability}

For enterprise development, the cooperation stability of other enterprises is a very important part. There are multiple types of cooperative relations between enterprises, such as complete cooperation and coexistence of cooperation and competition. Different cooperative relations will give rise to difference influence on enterprise development. In addition, since the dependence degree of the enterprise sand other enterprises is different, the stability of enterprise cooperation will generates difference effects on the enterprise. But on the whole, higher stability of enterprise cooperation will shows better development prospect and higher market share of the enterprise. The dependence degree of enterprise development on cooperation will of other enterprises also lies on enterprise's market strategy and product positioning. These have very close relationship with product price factor. From another perspective, the influence of product price on enterprise cooperation will stability is mainly reflected in strategic planning of product positioning and market expansion ${ }^{[2]}$.

On the one hand, the stability of enterprise cooperation will reflects enterprise development prospect; on the other hand, it reflects enterprise brand value, while brand value is very significant for enterprise development. Enterprises will certainly reach certain product market share in order to improve their brand value. In other words, enterprises will certainly hope the stability of enterprise cooperation will keeps a high level in order to improve brand value, keep market share and increase total profit. Under different external economic environment and market environment, the stability of enterprise cooperation will is every changing. When external economic environment is good and market demand is great, the stability of enterprise cooperation will will be certainly enhanced. When external economic environment is poor and market demand is low, the stability of enterprise cooperation will will certainly decrease. In other words, external economic environment also influences the stability of enterprise cooperation will, except product price factor. Especially when global economic development speed slows down and economic growth declines, such phenomenon is particularly obvious. In such case, the influence of product price on enterprise cooperation will will decrease.

\section{Influence of product price competition and cooperation on stability of enterprise cooperation}

The influence of product price competition and cooperation on the stability of enterprise cooperation will is reflected in many aspects, and the forms are also diversified. Although certain linear proportional relation is presented on the whole, there are difference influence relations under different external economic environment and market environment. The influence of product price competition and cooperation on the stability of enterprise cooperation will presents certain linear proportional relation. For example, when an enterprise decreases product price, the stability of enterprise cooperation will will certainly grow. When an enterprise increases product price, the stability of enterprise cooperation will will decrease. The change in the stability of enterprise cooperation will with the change in product price does not show a constant proportional relation or an influence relation with the same range. There are many factors influencing the stability of enterprise cooperation will. Although product price competition and cooperation are very important factors, enterprises will adopt difference strategies in different period and different external market environment, thus influencing the stability of enterprise cooperation will.

The change modes of enterprise cooperation will stability are also diversified. Although corresponding changes will occur due to product price change, similar expression form will not be always presented. In other words, the change in enterprise cooperation will stability will generate 
diversified change forms due to the change in product price. Among these change forms, there are certain rules. On the hole, any change form will conform to economic law and generate inverse proportion of growth or decrease in enterprise cooperation will stability due to product price change. However, the change range will be influenced by many other factors. In addition, product price change is a factor which can be quantified, while the stability of enterprise cooperation will cannot be accurately quantified. Thus, quantified and accurate influence relation cannot be gained, but corresponding influence relationship will be presented. On this basis, enterprises should take different product price adjustment strategies to maximize enterprise profit in accordance with different external market economic environment and maintain the stability of enterprise cooperation will at a high level.

\section{Strategies to adjust product price in a balanced way and enhance stability of enterprise cooperation}

Product price decrease, enterprise profit increase and enterprise development promotion are not a refutation. The influence relation between product price competition and cooperation, and enterprise cooperation will stability is a good example. For an enterprise, how to adjust product price in an balanced way, make product price in an optimal range, and contribute to maintaining high enterprise cooperation will and improving overall profit level so as to guarantee market share of enterprise products and promote enterprise development is the crucial point. For enterprise development, product and market are the most important aspects, while product quality control, design, innovation and market positioning are the preconditions of enterprise survival. Enterprises can gain survival only when product the products with market value. This is the root of enterprise survival. Enterprise product market is the key for enterprises to gain development and even develop on a large scale. Especially in current conditions of economic development decline and slow global economic development, enterprises must pay attention to market and actively expand product market.

To effectively expand market and maintain certain market share, enterprises must have high stability of enterprise cooperation will. This is an effective means to expand development and maintain market share. To get higher stability of enterprise cooperation will, product price must be adjusted in different period according to different external market and economic environment so as to reach economic development in a rational range, improve the stability of enterprise cooperation will and ensure enterprise market expansion and share ${ }^{[3]}$. When an enterprise adjusts the price, scientific and detailed market survey should be carried out. Meanwhile, cooperation will stability of partners should be evaluated according to actual conditions of the enterprise, and corresponding evaluation results should be established in accordance with the influence of product price on enterprise cooperation will stability so as to offer decision basis for the enterprise and make correct product price adjustment strategy. In other words, product price adjustment strategy of an enterprise should be based on scientific and sound market survey and evaluation, and product price should not be adjusted subjectively. Product price adjustment should be combined with the influence of product price adjustment on enterprise cooperation will stability.

\section{Conclusion}

In enterprise development, on the one hand, product price adjustment is closely related to external market environment change; on the other hand, product price adjustment closely influences the stability of enterprise cooperation will. Product price change will lead to certain inverse proportion of influence on enterprise cooperation will stability. In other words, when product price declines, the stability of enterprise cooperation will will be enhanced. On the contrary, the stability of enterprise cooperation will will decrease. For enterprise development, how to find out the balance point of price adjustment and adjust product price in a scientific and rational range so as to improve the stability of enterprise cooperation will furthest, increase total profit and effectively promote enterprise development is the most crucial point. 


\section{Reference}

[1] Li Liangxian, Study on symbiotic behavior of growing process of SMEs based on competition and cooperation relationship, Jiangxi University of Finance and Economics, 2011.

[2] Su Tao, Study on enterprise cooperation and competition game in industrial cluster, Xi'an University of Architecture and Technology, 2012.

[3] Yan Ying, Zhao Gongmin, Function of cooperation will in gaining competitive advantage by enterprises in cluster, System Engineering, 2012,02:29-35. 